\title{
Editorial: With thanks to Ruth Fletcher
}

\author{
Yvette Russell $^{1}$
}

Published online: 20 April 2019

(c) Springer Nature B.V. 2019

In this first issue of 2019, and before I introduce the contents of the issue, we mark the end of Ruth Fletcher's five-year term as Academic Editor of Feminist Legal Studies (FLS). Ruth has had a significant impact on the direction of the journal over the course of her tenure and it is an intimidating prospect to step into the role after her. Ruth is a scholar of the highest calibre and integrity and her vision and passion for FLS has changed it irrevocably. Over the course of her tenure as Academic Editor the journal has increased its download rate by nearly 60 per cent and almost doubled its impact factor. Central to Ruth's vision for FLS when she took on the role of Academic Editor in 2014 was to make the journal a space in and through which feminist scholarship, activism and organising could meet. Many of her achievements over the last five years illustrate how successful she has been in realising that vision.

While FLS is very much run as a collective (see further: Fletcher 2015a; Fletcher et al. 2017, 12-15), the extraordinary amount of (uncompensated) work that has Ruth contributed to the journal over the last five years cannot be overstated. As the predatory nature of academic publishing becomes more widely reviled and large institutions begin to opt-out of the zero-sum game that is extortionate journal subscriptions, ${ }^{1}$ Ruth led many discussions and initiatives on the role of feminist publishing within this context. This critical work took on a number of elements, including: hosting events in which that discussion could be had; agitating for more open access spaces and provision within the journal; and using the editorial space that she negotiated for with our publisher to catalogue and archive these processes.

In 2016, and coinciding with its 25th anniversary, FLS hosted the inaugural Feminism, Legality and Knowledge conference (FLaK) at Queen Mary, University of London (Fletcher 2015b; Fletcher et al. 2016a, 2017). This event was very much developed and led by Ruth, who saw the need for a collaborative discussion between

\footnotetext{
1 See, for example, Editorial, 'The Guardian view on academic publishing: disastrous capitalism.' Guardian online (4 March 2019) https://www.theguardian.com/commentisfree/2019/mar/04/the-guard ian-view-on-academic-publishing-disastrous-capitalism; Lindsay Ellis, 'U. of California System Cancels Elsevier Subscriptions, Calling Move a Win for Open Access' (28 February 2019) Chronicle of Higher Education https://www.chronicle.com/article/U-of-California-System/245798.
}

Yvette Russell

yvette.russell@bristol.ac.uk

1 University of Bristol, Bristol, UK 
feminist activists and scholars around how to manage the paradoxes of the academy in which many of us exist and the role of the journal, if any, in resolving these. How might feminist legal studies, she asked:

- the approach and the journal-best use its food, equipment, techniques, time, space, mood, energy and commitment? How shall FLS scholars and associates make the most of what we have in a room that can sometimes be confining and confusing, yet also exciting and sustaining? How do others engage with the processes and products of our kitchen table? (Fletcher 2015b, 241).

So much of what Ruth has done with the journal over the last five years has been to think out loud about how feminist practices can be most effectively mobilised within the academy and the uncomfortable spaces, including those of academic publishing, it often forces us into (Fletcher et al. 2016b). To this end, Ruth has been at the forefront of insisting on the further provision of open access options in FLS. She spare-headed the negotiation with our publisher to request an open access space in each issue for an editorial. She envisioned the editorial as a place we could discuss current issues of concern to us, as well as introducing and curating our content. Her desire to confront and explore the discomfort and paradoxes, as well as the potentiality, of the academy and academic published is probably best crystallised by the editorial on 'Wench Tactics' she drafted in 2017 (Fletcher et al. 2017). In 'Wench Tactics', and consistent with the ideas generated by FLaK, Fletcher asks 'How does feminism enact openings and closings in conditions of violence?' (Fletcher et al. $2017,1)$. In her vision, and in order to have 'an impact on the access, use and circulation of our journal, even though we do not own the journal we edit', we must diversify the range of 'wench tactics' we draw upon. Such tactics might include 'adapting gifts, stalling and resting' and provide us with an alternative to more obvious tactics of resignation or withdrawing labour from editing and reviewing entirely (Fletcher et al. 2017, 1). Fletcher detailed our own deployment as an editorial board of wench tactics in the process of negotiating more acceptable terms with our publisher and politicised it as an attempt to 'use our collective academic belonging to hold publishers to account' (Fletcher et al. 2017, 16). By 'being difficult' or becoming a 'wench in the works' (Franklin 2015), we deployed the tactic of stalling on the production of compiling the print editions of the journal. By failing to observe Springer practices and procedures, we sought to draw attention to the editorial work we do without compensation and to enhance our negotiating position in respect of our contractual terms. Although the wench tactics we used proved successful in allowing us to achieving the modest goals we set, Fletcher remained philosophical about the place and role of this type of activism within and outside the academy, always attentive to the paradoxical reality we inhabit.

This scattering of FLaK, and repurposing of shrapnel, has potential as an alternative to linear approaches to knowledge generation and impact. It focuses instead on feminist methods of working with the pain and pleasure of where we are in our research arrangements as we strive to make other worlds out of what we have. (Fletcher et al. 2017, 19) 
Wench tactics is a good example of the difficult balance that Ruth sought to strike at FLS by providing a feminist forum in which scholars could have a place to publish their work, but also while maintaining a healthy skepticism of the tyranny of metrics and the need to playfully and purposefully undermine these where possible. As an editorial board we continue to reflect on feminist publishing as tactics and our role in curating the canon.

Another key concern of Ruth's during her tenure as Academic Editor was to think about how the journal might be more effectively 'internationalised' (Fletcher et al. 2016a), or how it can better encourage and foreground the work of Global South feminist scholars. She initiated the current collaboration the journal enjoys with the Socio-Legal Journals Global South Writing Workshops led by Ambreena Manji at Cardiff University and funded by the British Academy. ${ }^{2}$ This initiative has enabled us to think more carefully about feminist epistemology in the context of FLaK, and we hope to continue that conversation with forthcoming events in the name of FLS.

On behalf of the editorial board of Feminist Legal Studies, I offer Ruth our sincere thanks for her passion, vision and leadership over the last five years. ${ }^{3}$ In what follows, I briefly introduce the articles, reflections and reviews contained within this issue of the journal.

\section{This issue}

Elsje Bonthuys' article, 'What's the Deal? Women's Evidence and Gendered Negotiations' considers relationship property law in South Africa with a focus on the evidential requirements placed on women trying to assert a claim to property after the dissolution of a non-marital intimate partnership (2019). Bonthuys argues that there is an important link to be made between the treatment of such claims and the evidence of woman complainants in criminal rape trials. In both cases, courts are often reluctant to give credence or attach evidentiary value to women's testimony habitually relying on staid stereotypes and prejudices about both men and women. Common to both the resolution of relationship property and rape cases is a conceptual reliance on notions of consent that are infused with normative assumptions about heterosexual sexuality and about the respective entitlements of men and women in or exiting relationships. The article seeks to illustrate how social beliefs and mores about the testimony of women that feminists have exposed so effectively through the study of sexual violence is present and relevant too beyond the criminal law.

In 'Gender Injustice in Compensating Injury to Autonomy in English and Singaporean Negligence Law' Tsachi Keren-Paz investigates the remedies offered by English law for injury to autonomy as a stand-alone actionable damage in negligence (2019). He argues that as well as being substantively problematic in its scope and application, it also discriminates against women claimants. Situating the argument within the broader feminist literature critical of tort law and its capacity or will

\footnotetext{
2 See further: https://www.lawandglobaljustice.com/sociolegal-journals-global-south-initiative.

3 Ruth will remain on the FLS editorial board.
} 
to addressed harms against women, Keren-Paz insists that the failure to grasp the meaning or importance of women's interests in reproductive autonomy explains the inadequacy of remedies for injury to autonomy. With reference to English case law on imposed motherhood, Keren-Paz illustrates the disparate treatment of harms to the reproductive autonomy of men and women. The cases illustrate a tendency on the part of courts to rationalise imposed motherhood and to refuse to recognise it as a detriment to women, thus undermining autonomy. Keren-Paz explores the recent case of $A C B v$ Thomson Medical Pte Ltd, ${ }^{4}$ in which the Supreme Court of Singapore awarded compensation for undermining the claimant's genetic affinity in a case of wrongful fertilization. This decision, he asserts, demonstrates some improvement in comparison to English law gesturing towards a context in which gendered injustice in cases implicating reproductive autonomy are shared. However, the case remains marred by conceptual inconsistencies and inattention to the gendered aspects of reproductive autonomy prioritising a father's genetic affinity with the baby over a woman's interest against forced motherhood.

Lisa Featherstone and Alexander George Winn chart a genealogy of marital rape law reform in South Australia in the 1970s in 'Marital Rape and the Marital Rapist: The 1976 South Australian Rape Law Reforms' (2019). Drawing on media reports and Parliamentary debates of the time, Featherstone and Winn argue that an appraisal of the discourse surrounding these laws reveal a telling reliance for their successful passage on the construction of the marital rapist as a certain type of man. In their reading, the marital rapist is cast as a sexual deviant whose aberrance from patriarchal standards of decency and normativity render him deserving of sanction. This tendency to attach the criminality to the man himself in these cases, rather than the act of rape, was buttressed by and grounded in patriarchal ideas about marriage and marital obligation. The authors show how the archetypal image of the 'beastly' husband rapist who sadistically assaulted his wife was mobilised to justify the passage of marital rape laws in South Australia in 1976 and as an example of those men who were deserving of criminal sanction for rape in marriage. This emphasis on the marital rapist as 'beast' or deviant other fed in, argue Featherstone and Winn, to the eventual watered-down version of the laws which required proof of the existence of aggravating circumstances in addition to intentional penetration without consent. The implication of this reform then being that marriage was an institution in which decent men protected and respected their vulnerable wives, and marital rapists could only be distinguished by their unambiguous brutality, which affronted all notions of patriarchal decency.

Accompanying these three articles in this first issue of 2019, we publish two reflections pieces both of which concern feminist scholarship and the international legal context. In their 'Inter-Generational Conversation', Hilary Charlesworth, Gina Heathcote and Emily Jones reflect on the role of feminist scholarship in international law from the 1990s to the present day (2019). In a dynamic and unpredictable international legal and political arena, they ask, how does feminist scholarship retain its salient critical voice? The reflection tells the story of the feminist perspective on

\footnotetext{
${ }^{4}$ [2017] SGCA 20.
} 
international law through a discussion between three generations of feminist international legal scholars: Hilary Charlesworth, who, with her colleagues, contributed to the area in the immediate post-Cold War years, Gina Heathcote, who over the past decade has published extensively on feminist perspectives on the use of force and collective security, and Emily Jones, an early career scholar working on feminist approaches to international law. The conversation reflects on the foregoing two decades for feminist approaches to international law while also looking to the future, including the need to challenge and diversify existing feminist international legal scholarship. The discussants consider the ways in which feminist perspectives remain shut out of mainstream international legal circles and talk about the need to balance cultivating and fostering a space in which feminists can come together to discuss the issues pertinent to the field, while also insisting on their inclusion in mainstream discourse.

In her reflection on 'Women, Peace and Security', Laura Davis considers how these themes have been translated into policy and practice by the European Union and the Democratic Republic of Congo (2019). Davis argues that an appraisal of the Women, Peace and Security agenda within these two contexts reveals notable gains by women peacebuilders, but also important challenges. These challenges include a failure of the agenda to address broader materialist feminist concerns and the use of Women, Peace and Security to promote and sustain heteronormativity and normative understandings of gender. Such failure, Davis argues, reveals the limits to such an agenda in this particular area of international feminist policy and practice.

Finally, the issue is completed by two book reviews, both of which consider important recent texts in the field of international queer feminist scholarship. Swethaa Ballakrishnen reviews Ratna Kapur's Gender, Alterity, and Human Rights: Freedom in a Fish Bowl (2018) and Emily Jones reviews the recent edited collection by Dianne Otto, Queering International Law: Possibilities, Alliances, Complicities, Risks (2017).

We take this opportunity to offer thanks to our peer reviewers whose work is an essential part of enabling the journal to function as it does and for whose care and generosity authors and the board are deeply grateful.

\section{References}

Bonthuys, Elsje. 2019. What's the deal? Women's evidence and gendered negotiations. Feminist Legal Studies. https://doi.org/10.1007/s10691-018-9391-2.

Charlesworth, Hilary, Gina Heathcote, and Emily Jones. 2019. Feminist scholarship on international law in the 1990s and today: An inter-generational conversation. Feminist Legal Studies. https://doi. org/10.1007/s10691-018-9384-1.

Davis, Laura. 2019. Women peace and security: Adrift in policy and practice. Feminist Legal Studies. https://doi.org/10.1007/s10691-018-9381-4.

Featherstone, Lisa, and Alexander George Winn. 2019. Marital rape and the marital rapist: The 1976 South Australian Rape Law Reforms. Feminist Legal Studies. https://doi.org/10.1007/s1069 1-018-9382-3.

Fletcher, Ruth. 2015a. Responding to submissions and introducing issue 23 (1). Feminist Legal Studies 23 (1): 1-6. 
Fletcher, Ruth. 2015b. FLaK: Mixing feminism, legality and knowledge. Feminist Legal Studies 23 (3): 241-252.

Fletcher, Ruth, Julie McCandless, Yvette Russell, and Dania Thomas. 2016a. Internationalism and commitment at the kitchen table. Feminist Legal Studies 24 (1): 1-6.

Fletcher, Ruth, Julie McCandless, Yvette Russell, and Dania Thomas. 2016b. On being uncomfortable. Feminist Legal Studies 24 (2): 121-126.

Fletcher, Ruth, Diamond Ashiagbor, Nicola Barker, Katie Cruz, Nadine El-Enany, Nikki Godden-Rasul, Emily Grabham, Sarah Keenan, Ambreena Manji, Julie McCandless, Sheelagh McGuinness, Sara Ramshaw, Yvette Russell, Harriet Samuels, Ann Stewart, and Dania Thomas. 2017. Wench tactics? Openings in conditions of closure. Feminist Legal Studies 25 (1): 1-23.

Franklin, Sarah. 2015. Sexism as a means of reproduction: Some reflections on the politics of academic practice. New Formations 86: 15-33.

Kapur, Ratna. 2018. Gender, alterity, and human rights: Freedom in a fish bowl. London: Edward Elgar.

Keren-Paz, Tsachi. 2019. Gender injustice in compensating injury to autonomy in English and Singaporean Negligence Law. Feminist Legal Studies. https://doi.org/10.1007/s10691-018-9390-3.

Otto, Dianne (ed.). 2017. Queering international law: Possibilities, Alliances, complicities, risks. London: Routledge.

Publisher's Note Springer Nature remains neutral with regard to jurisdictional claims in published maps and institutional affiliations. 